\title{
UJI DAYA HAMBAT NANOPARTIKEL EKSTRAK RIMPANG LENGKUAS MERAH (Alpinia purpurata K. Schum) TERHADAP PERTUMBUHAN BAKTERI Klebsiella pneumoniae ISOLAT URIN PADA PENDERITA INFEKSI SALURAN KEMIH RESISTEN ANTIBIOTIK CIPROFLOXACIN
}

\author{
Misella Regina C. Lasut ${ }^{1)}$, Fatimawali ${ }^{1)}$, Irma Antasionasti ${ }^{1)}$ \\ ${ }^{1)}$ Program Studi Farmasi FMIPA UNSRAT Manado, 95115
}

\begin{abstract}
Nanoparticles can increase the solubility of compounds, reduce the treatment dose and increase absorption. Flavonoid and phenol compounds in red galangal can inhibit the growth of bacteria that have been resistant to antibiotics. The bioactivity of red galangal compounds is expected to increase when the size of nanoparticles increases antibacterial activity. This study aims to determine the inhibition of the content of Red Galangal nanoparticles (Alpinia purpurata K.Schum) using chitosan on the growth of Klebsiella pneumoniae bacterial urine isolates of UTI antibiotic-resistant Ciprofloxacin. Nanoparticles extracts of red galangal rhizome was made using ionic gelation method, using extract concentration of $0.4 \%$, tested for antibacterial activity using the wells method with a comparison of chitosan $0.4 \%$, acetic acid $5 \%$, red galangal extract $25 \%$. Red galangal rhizome nanoparticles gave antibacterial activity value to the bacteria Klebsiella pneumoniae of $13.5 \mathrm{~mm}$. Therefore, red galangal extracts nanoparticles can inhibit the growth of Klebsiella pneumoniae urine isolate in patients with urinary tract infections with strong inhibitory categories based on Davis and Stout categories.
\end{abstract}

Keywords: Alpinia purpurata K. Schum, Klebsiella pneumonia, Nanoparticles.

\begin{abstract}
ABSTRAK
Nanopartikel dapat meningkatkan kelarutan senyawa, mengurangi dosis pengobatan dan meningkatkan absorbsi. Senyawa flavonoid dan fenol dalam lengkuas merah mampu menghambat pertumbuhan bakteri yang telah resisten terhadap antibiotik. Sifat bioaktivitas senyawa lengkuas merah diharapkan akan meningkat ketika berukuran nanopartikel untuk meningkatkan aktivitas antibakteri. Penelitian ini bertujuan untuk mengetahui daya hambat kandungan nanopartikel rimpang Lengkuas Merah (Alpinia purpurata K.Schum) menggunakan kitosan terhadap pertumbuhan bakteri Klebsiella pneumoniae isolat urin penderita ISK yang resisten antibiotik Ciprofloxacin. Nanopartikel ekstrak rimpang lengkuas merah dibuat dengan menggunakan metode gelasi ionik, dengan menggunakan konsentrasi esktrak sebesar $0,4 \%$, dilakukan pengujian aktivitas antibakteri mengunakan metode sumuran dengan pembanding kitosan $0,4 \%$, asam asetat 5\%, ekstrak lengkuas merah 25\%. Nanopartikel rimpang lengkuas merah memberikan nilai aktifitas antibakteri terhadap bakteri Klebsiella pneumoniae sebesar 13,5 mm. Oleh karena itu nanopartikel ekstrak rimpang lengkuas merah dapat menghambat pertumbuhan bakteri Klebsiella pneumoniae isolate urin penderita infeksi saluran kemih dengan kategori daya hambat kuat berdasrkan kategori Davis dan Stout.
\end{abstract}

Kata Kunci: Alpinia purpurata K. Schum, Nanopartikel, Klebsiella pneumoniae. 


\section{PENDAHULUAN}

Aplikasi teknologi nanopartikel dalam bidang farmasi mempunyai berbagai keunggulan antara lain dapat meningkatkan kelarutan senyawa, mengurangi dosis pengobatan dan meningkatkan absorbsi. Saat ini, sintesis nanopartikel secara biologi lebih disukai dibandingkan metode fisikokimia, karena dinilai lebih memiliki banyak keuntungan, diantaranya : lebih ecofriendly, non-toxic, lebih reproducible dan morfologinya lebih baik (Kim, 2015).

Sumber sintesis nanopartikel secara biologi adalah mikroorganisme dan tanaman. Namun demikian, dalam prakteknya penggunaan tanaman untuk sintesis nanopartikel lebih disukai dibandingkan dengan mikroorganisme karena berbagai alasan, diantaranya: langkah yang lebih sederhana, lebih cepat, lebih cost-effective, lebih biocompatible sehingga lebih aplikatif untuk digunakan dalam ranah medis (Kim dkk, 2016). Sekian banyak tanaman yang bisa dimanfaatkan, salah satunya adalah lengkuas merah (Alpinia purpurata K.Schum). Kandungan metabolit sekunder dalam lengkuas merah adalah flavonoid, fenol yang diduga mampu menghambat pertumbuhan bakteri yang telah resisten terhadap antibiotik (Yuharmen dkk, 2002).

$$
\text { Sikome (2018) di Manado }
$$

melaporkan bahwa hasil uji resistensi dengan 17 isolat menunjukan ciprofloxacin memiliki persentase resisten 47,06 \% dan sensitif sebesar 52,94\% terhadap Bakteri yang berhasil diidentifikasi dari 1 isolat dengan resistensi tinggi yaitu Klebsiella pneumoniae. Selain itu Klebsiella pneumoniae telah menjadi masalah serius di rumah sakit sebagai akibat dari penyebaran infeksi nosokomial melalui kateterisasi urin (Aly, 2016).
Salah satu upaya yang dapat dilakukan dalam mengatasi resistensi adalah mengkombinasikan antibiotik dengan tanaman yang memiliki aktivitas antibakteri dari antibiotik (Useng, 2014). Dalam hal ini, sifat bioaktivitas senyawa lengkuas merah diharapkan akan meningkat ketika berukuran nanopartikel untuk meningkatkan aktivitas antibakteri. Modifikasi penelitian mengenai nanopartikel menggunakan kitosan telah banyak dilakukan baik dalam proses kimia maupun fisik dengan mengubah ukuran partikel kitosan yaitu dalam bentuk nanopartikel. Nanopartikel menggunakan kitosan memiliki daya serap dan kemampuan yang lebih baik sebagai senyawa antibakteri (Karmelia 2009). Kitosan dimanfaatkan sebagai antibakteri dilihat dari kemampuan muatan positifnya berinteraksi dengan permukaan sel bakteri bermuatan negatif, sehingga dapat mengganggu pertumbuhan koloni bakteri (Goy dkk, 2009).

Berdasarkan latar belakang diatas, maka penulis tertarik untuk melakukan penelitian uji daya hambat nanopartikel rimpang lengkuas merah (Alpinia purpurata K.Schum) terhadap pertumbuhan bakteri Klebsiella pneumoniae K. Schum yang diisolasi dari urin penderita Infeksi Saluran Kemih yang resisten antibiotik Ciprofloxacin.

\section{METODOLOGI PENELITIAN}

Penelitian ini dilakukan pada bulan Maret sampai Juni 2019 di Laboratorium Mikrobiologi, Program studi Farmasi Fakultas Matematika dan Ilmu Pengetahuan Alam, Universitas Sam Ratulangi Manado.

Alat yang digunakan dalam penelitian ini yaitu gelas ukur (Pyrex), Erlenmeyer (Pyrex), tabung reaksi (Pyrex), corong, ayakan mesh 200, pisau, timbangan analitik (aeADAM®), blender 
(Philips), thermometer, sudip, beker gelas (Pyrex), cawan petri (Pyrex), autoklaf (ALP), Laminar Air Flow (N-Bioteck), incubator (MMM Group), Alat Destilasi, Ose, pingset, L glass, pipet mikro (ecopippette ${ }^{\mathrm{TM}}$ ), mistar berskala (Combo®) aluminium foil, kertas saring, kertas lebel dan spritus.

Bahan yang digunakan dalam penelitian ini meliputi rimpang Lengkuas Merah (Alpinia purpurata K.Schum), Kitosan, Na-TPP, Polysorbat 80, bakteri Klebsiella pneumoniae, antibiotik ciprofloxacin, aquadest, etanol 96\%, $\mathrm{H} 2 \mathrm{SO} 4$ $1 \%, \mathrm{BaCl} 2.2 \mathrm{H} 2 \mathrm{O} 1,175 \%, \mathrm{NaCl} 0,9 \%$, media Nutrient Agar, Larutan standar Mc. Farland 0,5.

Jenis penelitian ini merupakan eksperimental laboratorium dengan sampel rimpang lengkuas merah $0,4 \%$ dan dilakukan pengujian pada bakteri.

\section{Persiapan Sampel}

Sampel yang digunakan diambil dari kelurahan Rurukan, Kecamatan Tomohon Timur, Tomohon, Sulawesi Utara. Sampel yang diambil ialah bagian rimpang Lengkuas merah yang masih segar. Pada tahap awal sampel rimpang Lengkuas merah ditimbang dengan berat $1,5 \mathrm{~kg}$. Selanjutnya dicuci dengan air mengalir dengan tujuan menghilangkan pengotor. Sampel kemudian dirajang untuk mempermudah proses pengeringan. Pengeringan sampel dilakukan dengan cara diangin-anginkan selama 1 minggu.

\section{Pembuatan Ekstrak}

Metode yang digunakan untuk mengekstrak rimpang Lengkuas merah (Alpinia purpurata K.Schum), yaitu dengan menggunakan metode maserasi. Sebanyak 1,5 $\mathrm{kg}$ rimpang Lengkuas merah, dikeringkan dan dihaluskan menjadi serbuk simplisia. Sampel yang telah ditimbang diekstraksi dengan $750 \mathrm{~mL}$ etanol $96 \%$ pada suhu kamar selama 5 hari sambil sesekali diaduk. Setelah 5 hari sampel disaring dengan menggunakan kertas saring menghasilkan filtrat satu. Sisanya dimaserasi kembali dengan $450 \mathrm{~mL}$ pelarut etanol $96 \%$ selama 2 hari sambil sesekali diaduk kemudian di saring dengan kertas saring menghasilkan filtrat dua. Filtrat satu dan filtrat dua dikumpulkan dan diuapkan, sehingga diperoleh ekstrak kental lengkuas merah.

\section{Pembuatan Media Dasar dan Media Pembenihan}

Diambil Nutrient Agar (NA) sebanyak 5,6 gram dilarutkan dalam $200 \mathrm{~mL}$ aquadest menggunakan erlenmeyer. Setelah itu, media dihomogenkan dengan stirer di atas penangas air sampai mendidih. Media yang sudah homogen ini disterilkan dalam autoklaf pada suhu $121^{\circ} \mathrm{C}$ selama 15 menit, kemudian didinginkan sampai suhu \pm 45 $50^{\circ} \mathrm{C}$. Media dasar dan media pembenihan digunakan dalam pembuatan media pengujian sebagai lapisan dasar dan lapisan kedua.

\section{Pembuatan Larutan Mc. Farland 0,5 (standart kekeruhan)}

Larutan $\mathrm{H}_{2} \mathrm{SO}_{4} 1 \%$ sebanyak $9,95 \mathrm{~mL}$ dicampurkan dengan larutan $\mathrm{BaCl}_{2} \cdot 2 \mathrm{H}_{2} \mathrm{O}$ $1,175 \%$ sebanyak $0,05 \mathrm{~mL}$ dalam erlenmeyer. Kemudian dikocok sampai terbentuk larutan yang keruh. Kekeruhan ini dipakai sebagai standar kekeruhan suspensi bakteri uji (Borges dan Bresson, 2004).

\section{Suspensi Bakteri}

Bakteri uji pada media agar miring diambil dengan jarum ose steril lalu 
disuspensikan dengan cara dimasukkan ke dalam tabung yang berisi $5 \mathrm{~mL}$ larutan $\mathrm{NaCl}$ steril $0,9 \%$. Suspensi yang terbentuk disetarakan kekeruhannya dengan larutan Mc. Farland 0,5.

\section{Pembuatan Larutan Kontrol Positif dan Larutan Kontrol Negatif}

Larutan kontrol positif dibuat dari sediaan obat tablet ciprofloxacin $500 \mathrm{mg}$, dengan cara satu tablet ciprofloxacin digerus. Setelah itu ditimbang sebanyak 50 mg dan dilarutkan dalam $50 \mathrm{~mL}$ aquades. Selanjutnya diambil $1 \mathrm{~mL}$ dan ditambahkan aquades hingga $10 \mathrm{~mL}$ untuk memperoleh larutan ciprofloxacin $5 \mu \mathrm{g} / 50 \mu \mathrm{l}$. Larutan kontrol negatif digunakan aquadest.

\section{Pembuatan Larutan Kitosan}

Kitosan ditimbang sebanyak 0,4 gram kemudian kitosan dilarutkan dengan larutan asam asetat $5 \% \mathrm{v} / \mathrm{v}$ hingga $100 \mathrm{ml}$ dan diaduk dengan pengaduk magnetik hingga larut.

\section{Pembuatan larutan Na-TPP}

Natrium Tripolifosfat (Na-TPP) ditimbang masing-masing sebanyak 0,1 gram kemudian dilarutkan dengan aquadest hingga $100 \mathrm{ml}$ kemudian diaduk dengan pengaduk magnetik hingga larut.

\section{Penyiapan Ekstrak Lengkuas Merah}

Sebanyak 0,1 gram ekstrak lengkuas merah ditimbang dan dilarutkan dalam etanol 96\% sebanyak $4 \mathrm{ml}$ dan dilakukan sonikasi selama 10 menit.

\section{Pembuatan Nanopartikel Ekstrak Lengkuas Merah}

Larutan kitosan 0,4\% dimasukkan ke dalam gelas beaker sebanyak $100 \mathrm{ml}$.
Kemudian ditambahkan polysorbat 80 sebanyak $1 \mathrm{ml}$ dan diaduk menggunakan pengaduk magnetik dengan kecepatan 1000 rpm selama 10 menit. Setelah itu, pada larutan kitosan 0,4\% dimasukkan 0,1 gram ekstrak Lengkuas Merah dan diaduk dengan menggunakan homogenizer dengan kecepatan $1500 \mathrm{rpm}$ selama 30 menit. Setelah itu, ke dalam larutan kitosan 0,4\% ditambahkan larutan Na-TPP sebanyak $20 \mathrm{ml}$ lalu dihomogenizer pada kecepatan $1500 \mathrm{rpm}$ selama 90 menit.

\section{Uji Aktivitas Antibakteri secara In-vitro}

Larutan uji nanopartikel rimpang lengkuas merah dengan konsentrasi $0,4 \%$; larutan kitosan 0,4\%: ekstrak lengkuas merah 25\%; aquadest sebagai kontrol negatif; larutan Ciprofloxacin $5 \mu \mathrm{g} / 50 \mu \mathrm{l}$ sebagai kontrol positif, masing-masing diteteskan pada sumur yang berbeda sebanyak $50 \mu 1$ Kemudian cawan petri diinkubasi dalam inkubator pada suhu $37^{\circ} \mathrm{C}$ selama $1 \times 24$ jam.

\section{Pengamatan dan Pengukuran}

Pengamatan dilakukan setelah 1x24 jam masa inkubasi. Daerah bening merupakan petunjuk kepekaan bakteri terhadap antibiotik atau bahan antibakteri lainnya yang digunakan sebagai bahan uji yang dinyatakan dengan lebar diameter zona hambat. Diameter zona hambat diukur dalam satuan milimeter $(\mathrm{mm})$ menggunakan mistar berskala dengan cara diameter keseluruhan dikurangi diameter sumuran $7 \mathrm{~mm}$. Kemudian diameter zona hambat tersebut dikategorikan kekuatan daya antibakterinya berdasarkan penggolongan Davis and Stout (1971). 


\section{HASIL DAN PEMBAHASAN Ektraksi}

Sampel rimpang lengkuas merah seberat $1,5 \mathrm{~kg}$, dikeringkan dan dihaluskan menghasilkan serbuk simplisia sebanyak 100 gram, selanjutnya diekstraksi dengan metode maserasi menggunakan pelarut etanol $96 \%$ sebanyak $750 \mathrm{~mL}$. Proses maserasi dilakukan $3 \times 24$ jam dengan dua kali remaserasi atau pergantian pelarut yang baru. Hasil maserasi selanjutnya diuapkan menggunakan oven dengan suhu $40^{\circ} \mathrm{C}$ sehingga diperoleh ekstrak kental lengkuas merah sebanyak 5,8 gr.

\section{Nanopartikel Lengkuas Merah}

Nanopartikel ekstrak etanol Lengkuas Merah dibuat berdasarkan metode gelasi ionik antara kitosan dan Na-TPP. Proses pembuatan formulasi nanopartikel ekstrak Lengkuas Merah dilakukan dengan cara mereaksikan campuran kitosan, ekstrak Lengkuas Merah dengan natrium tripolifosfat (Na-TPP). Dengan mengatur konsentrasi kitosan dan Na-TPP, perbandingan konsentrasi antara kitosan dan Na-TPP yang digunakan sebagaimana pada metode penelitian ini yaitu kitosan $0,4 \%$ dan Na-TPP $0,1 \%$. Penetesan campuran Na-TPP dan Polysorbate 80 dalam larutan ekstrak lengkuas merah dan kitosan dilakukan dengan kecepatan konstan pengadukan tetap dilakukan selama 90 menit untuk menyempurnakan pembentukan nano partikel.

\section{Uji Aktivitas Antibakteri}

Tabel 1. Hasil Pengukuran Diameter Zona Hambat menggunakan Metode Sumuran

\begin{tabular}{ccccc}
\hline & \multicolumn{4}{c}{ Diameter Zona Hambat (mm) } \\
\cline { 2 - 5 } Perlakuan & UI & UII & UIII & $\begin{array}{c}\text { Rata- } \\
\text { rata }\end{array}$ \\
\hline Kontrol (-) & 0 & 0 & 0 & 0 \\
Kontrol (+) & 11,5 & 12 & 11 & 11,5 \\
Nanopartikel & 13 & 14 & 13,5 & 13,5 \\
Kitosan 0,4\% & 4,5 & 7 & 5 & 5,5 \\
Asam Asetat & 9 & 7,5 & 7,5 & 8 \\
Ekstrak 25\% & 2,5 & 2 & 2,5 & 2,3 \\
\hline
\end{tabular}

Uji daya hambat ekstrak Lengkuas merah terhadap bakteri Klebsiella pneumoniae menggunakan metode difusi sumur, digunakan metode ini agar supaya cocok digunakan untuk komponen yang berbahan dasar cair kerena komponen tersebut dapat berdifusi baik ke dalam media agar padat. Metode ini menggunakan media Nutrient Agar (NA). Media Nutrient Agar (NA) merupakan medium yang baik sebagai tempat tumbuhnya beberapa bakteri gram positif dan gram negatif yang dimanfaatkan sebagai sumber nutrisi bagi pertumbuhan bakteri. Dalam uji efektivitas hasil diperoleh melalui pengamatan yang dilakukan selama $1 \times 24$ jam masa inkubasi pada suhu $37^{\circ} \mathrm{C}$ dengan 3 kali pengulangan.

Pengujian ini menggunakan kontrol positif dan kontrol negatif. Kontrol positif berfungsi sebagai kontrol dari zat uji dengan membandingkan diameter daerah hambat yang terbentuk (Dwijendra, 2014). Kontrol positif menggunakan Ciprofloxacin. Ciprofloxacin dipilih sebagai kontrol positif untuk melihat apakah bakteri Klebsiella pneumoniae yang diujikan benar resisten terhadap antibiotik ciprofloxacin. Menurut Sarro (2001) antibiotik Ciprofloxacin merupakan antibiotik dengan spektrum luas, yaitu antibiotik yang memiliki aktivitas 
banyak jenis bakteri, virus, jamur dan protozoa. Pada penelitian ini, didapatkan hasil adanya zona hambat yang terbentuk di sekitar sumur yang diberi antibiotik ciprofloxacin. Dalam pengujian zona hambat dikategorikan kuat dengan ukuran $11,5 \mathrm{~mm}$ akan tetapi pada zona hambat masih terbentuk sel bakteri yang manandakan bakteri Klebsiella pneumoniae resisten terhadap antibiotik ciprofloxacin. Bakteri menjadi resisten terhadap antibiotik dapat mengubah permukaan selnya sehingga antibiotik tidak lagi mampu membunuh sel bakteri (Schulz dkk, 2016). Sel resisten terjadi dengan adanya penurunan membran sel terhadap antibiotik dan variasi jalur metabolisme tersebut oleh antibakteri. Akibatnya obat tersebut tidak efektif lagi bagi bakteri (Setyabudy dkk, 1995). Kontrol negatif digunakan untuk mengetahui ada tidaknya pengaruh pelarut terhadap pertumbuhan bakteri uji sehingga dapat diketahui bahwa aktivitas yang ditunjukan ialah zat yang terkandung dalam sampel bukan berasal dari pelarut yang digunakan. Dalam pengujian kontrol negatif aquades tidak menunjukkan adanya daya hambat terhadap bakteri uji.

Tabel 2. Standar Kekuatan Daya Antibakteri Menurut Davis dan Stout (1971)

\begin{tabular}{cc}
\hline $\begin{array}{c}\text { Diameter Zona } \\
\text { Bening } \\
(\mathbf{m m})\end{array}$ & Kategori \\
\hline$<5$ & Lemah \\
$5-10$ & Sedang \\
$11-20$ & Kuat \\
$>20$ & Sangat Kuat \\
\hline
\end{tabular}

Pengujian aktifitas antibakteri nanopartikel ekstrak lengkuas merah memiliki zona hambat sebesar $13,5 \mathrm{~mm}$ dikategorikan memiliki aktifitas antibakteri kuat menurut standar kekuatan antibakteri Davis dan Stout (1971). Aktivitas antibakteri yang dihasilkan dari nanopartikel ekstrak lengkuas merah menunjukkan peningkatan dibandingkan dengan larutan kitosan yang hanya memiliki ukuran zona hambat $5,5 \mathrm{~mm}$ tergolong dalam kategori lemah. Hal ini disebabkan karena suspensi nanopartikel ekstrak lengkuas merah mempunyai aktifitas interaksi yang lebih besar terhadap sel bakteri dibandingkan dengan larutan kitosan saja. Semakin kecil ukuran partikel dari suspensi nanopartikel maka akan mempunyai sifat fisika kimia yang unik seperti luas permukaan yang besar dan reaktivitas yang besar dan karenanya dapat meningkatkan interaksi antar muatan pada permukaan bakteri dan mengakibatkan efek antibakteri yang lebih besar (Zhang dkk, 2004).

Asam asetat digunakan sebagai pelarut dari kitosan, digunakan sebagai pelarut karena sifat kitosan yang tidak dapat larut dalam air, hanya dapat larut dalam kondisi $\mathrm{pH}$ yang asam, namun asam asetat mempunyai aktivitas antibakteri. Oleh karena itu, dilakukan pengujian aktivitas antibakteri larutan asam asetat sebagai pembanding terhadap aktivitas antibakteri larutan kitosan. Dalam pengujian ini asam asetat memiliki daya hambat antibakteri sebesar $8 \mathrm{~mm}$ tergolong dalam kategori sedang.

Dalam pengujian zona hambat ekstrak lengkuas merah 25\% memiliki daya hambat antibakteri sebesar 2,3 $\mathrm{mm}$ tergolong dalam kategori lemah. Jika dibandingkan dengan penelitian yang dilakukan oleh Abubakar (2019) pada ekstrak Lengkuas Merah konsentrasi 25\%, besar zona hambat yang dihasilkan 4,5 $\mathrm{mm}$. Hal ini menunjukan bahwa hasil yang diperoleh selaras dengan penelitian 
sebelumnya atau sama-sama tergolong dalam kategori lemah. Abubakar (2019) juga menyatakan bahwa semakin besar konsentrasi ekstrak Lengkuas Merah yang diberikan, maka semakin besar pula diameter zona bening yang terbentuk. Adanya pengaruh senyawa bioaktif yang terdapat pada ekstrak Lengkuas merah seperti golongan senyawa flavonoid, tannin, kuinon dan terpenoid (Kusriani dkk, 2015). Senyawa-senyawa tersebut diduga merupakan senyawa yang berperan dalam menghambat pertumbuhan bakteri Klebsiella pneumoniae.

\section{KESIMPULAN}

Berdasarkan hasil penelitian yang dilakukan dapat disimpulkan bahwa Nanopartikel ekstrak rimpang Lengkuas Merah (Alpinia purpurata K.Schum) memiliki daya hambat terhadap bakteri Klebsiella pneumoniae isolat urin penderita infeksi saluran kemih. Dengan hasil pengukuran ratarata $13,5 \mathrm{~mm}$ dikategorikan daya hambat kuat berdasarkan teori Davis dan Stout.

\section{SARAN}

Perlu dilakukan penelitian lebih lanjut tentang potensi antibakteri dari zat aktif yang terdapat dalam ekstrak rimpang Lengkuas Merah.

\section{DAFTAR PUSTAKA}

Abubakar, Poetry Melinda S. Uji daya hambat ekstrak rimpang lengkuas merah (Alpinia purpurata K.Schum) terhadap pertumbuhan bakteri Klebsiella pneumoniae isolat sputum pada penderita pneumonia resisten antibiotik seftriakson. [skripsi]. Fakultas Matematika dan Ilmu Pengetahuan Alam, Universitas Sam Ratulangi. Manado. 2019.
Aly, S.A. 2016. Bacterial catheterassociated urinary tract infection in the intensive care unit of Assiut University Hospital. Al Azhar Assiut Medical Journal. 14:52-58.

Dwijendra, I. M. Aktivitas Antibakteri dan Karakterisasi Senyawa Fraksi Spos Lamellodysidea herbacea yang Diperoleh dari Teluk Manado. [skripsi]. Program Studi Farmasi FMIPA Universitas Sam Ratulangi, Manado. 2014.

Davis, W. W., T.R. Stout. 1971. Disc plate method of microbiological assay. Journal of microbiology 22: 659-665.

Goy RC, Douglas B, Odilio BGA. 2009. A review of the antimicrobial activity of chitosan. Journal Polymer. 19:1-7.

Karmelia S. Pengaruh derajat deasetilasi nano kitosan untuk menyerap ion Zn2+ dari limbah cair industri karet. [tesis]. Universitas Sumatera Utara. Medan. 2009.

Kim, Y. (2015). Biogenic silver and gold nanoparticles synthesized using red ginseng root extract, and their applications. Artificial Cells, Nanomedicine, and Biotechnology. International journal of nanomedicine. 10:3593-3601.

Kim, Y., Yang, D., Singh, P., Kim, Y., \& Zhang, D. (2016). Biological Synthesis of Nanoparticles from Plants and Microorganisms. International Journal of Pharmacy and Pharmaceutical Sciences. 7:387389.

Kusriani, R.H.,dan Shofia Az Zahra. 2015. Skrinning Fitokimia dan Penetapan Kadar Senyawa Fenolik Total Ekstrak Rimpang Lengkuas Merah dan Rimpang Lengkuas Putih (Alpinia galangal L.), Prosiding Seminar Nasional Penelitian dan PKM Kesehatan . 1:295-302. 
Sarro, A.D., G.D. Sarro. 2001. Adverse Reactions to Fluoroquinolones. An Overview on Mechanism Aspect. Current Medicinal Chemistry. 8 :371384

Sikome C., Fatimawali., Trina E. Tallei. 2018. Isolasi dan Identifikasi secara biomolekuler bakteri penyebab penyakit infeksi saluran kemih yang resisten terhadap antibiotik ciprofloxacin di RSUP. DR.R.D. Kandou Manado. Jurnal Ilmiah Farmasi Pharmacon. 7:62-70.

Setiabudy, R., Gunawan, S. G., Nafrialdi dan Elysabeth. 2009. Antimikroba. Balai Penerbit FK UI, Jakarta.

Useng, Asmah. Analisis Penggunaan Antibiotik Pada Penyakit Infeki Saluran Kemih Berdasarkan Evidance Base Medicine (EBM) di RSUD Dr. Moewardi Periode Januari-Juni 2013. [skripsi]. Universitas Muhamadiah. Surakarta. 2014.

Yuharmen, dkk. 2002. Uji Aktivitas Antimikroba Nanopartikel dan Ekstrak Methanol Lengkuas (Lenguas galang) Jurusan Kimia, FMIPA. Universitas Riau,Riau.

Zhang, H., Oh, M., Allen, C., Kumacheva. E. (2004). Monodisperse chitosan nanoparticles for mucosal drug delivery. Biomacromolecules. 5:2461-2468. 